\title{
Fluorimetric and microbiological assays of erythromycin concentrations in plasma and vaginal washings
}

\author{
A ILIOPOULOU,* R N THIN† AND P TURNER* \\ From the Departments of *Clinical Pharmacology and +Genital Medicine, St Bartholomew's Hospital, \\ London
}

SUMMARY Using a microbiological and a fluorimetric assay to determine penetration of erythromycin into vaginal fluids, concentrations were measured in plasma from nine men one hour after a single oral dose of erythromycin stearate $2 \mathrm{~g}$ and in vaginal washings and plasma samples taken simultaneously from 11 women two hours after the last dose of a 10-day course of erythromycin stearate ( $250 \mathrm{mg}$ four times daily).

Both assay methods gave accurate and reproducible results in plasma but only the fluorimetric method was capable of measuring concentrations of erythromycin in vaginal washings. The latter method had many advantages in estimating drug concentrations in body fluids such as vaginal washings and the results from it may provide an index of tissue penetration and of patient compliance in adhering to drug regimens.

\section{Introduction}

The measurement of drug concentrations in body fluids other than plasma is of increasing interest as it can lead to a greater knowledge of their distribution and tissue penetration. In particular, the clinical pharmacology and pharmacokinetics of antibiotics in vaginal secretions are areas of practical importance which have received little attention.

The concentration of antimicrobial agents in vaginal secretions probably follows the physicochemical aspects of non-ionic diffusion'; the $\mathrm{pH}$ gradient between plasma and vaginal fluid supports the application of this concept here.

Erythromycin is widely used in the treatment of non-specific infections. In this study, we determined the plasma concentrations in men and the plasma and vaginal secretion concentrations in women after therapeutic doses of erythromycin.

\section{Methods and patients}

MICROBIOLOGICAL ASSAY

An agar diffusion method with the test organism Sarcina lutea ATCC 9341, Difco antibiotic medium No 11, square plates $(23 \times 23 \mathrm{~mm})$, and incubation

Address for reprints: $\operatorname{Dr} \mathrm{R} N$ Thin, Department of Genital Medicine, St Bartholomew's Hospital, London EC1A 7BE

Accepted for publication 12 January 1981 for 24 hours at $37^{\circ} \mathrm{C}$ was used..$^{2} \mathrm{~A}$ standard curve was constructed from six standard solutions of erythromycin in serum $(0.05,0 \cdot 1,0 \cdot 25,1,2$, and $3 \mu \mathrm{g} / \mathrm{ml})$ and the test samples were estimated from it.

\section{FI.UORIMETRIC ASSAY}

This was based on the method of Tserng and Wagner ${ }^{3}$ using an Aminco (SPF-125) spectrofluorimeter.

\section{Plasma samples}

For plasma samples, the 1-ml test sample (diluted if known to be of high concentration) was estimated from a standard curve from five standard solutions prepared in plasma $(0,0.5,1,2$, and $3 \mu \mathrm{g} / \mathrm{ml})$ in duplicate.

\section{Vaginal washings}

For vaginal washings, the whole volume specimen $(40 \mathrm{ml})$ was estimated using a standard curve from four standard solutions $(0,0 \cdot 5,1$, and $2 \mu \mathrm{g} / \mathrm{ml})$ spiked (added) in blank vaginal washings in duplicate.

\section{SUBJECTS AND SAMPLES}

Nine men (aged 21-50 years) with gonococcal urethritis were given a 2-g oral dose of erythromycin stearate under supervision in the clinic; a 5-ml plasma sample was taken after one hour. 
Eleven women (aged 12-35 years) with non-specific genital infection were given oral erythromycin stearate $250 \mathrm{mg}$ four times daily for 10 days. Two hours after the last dose, vaginal washings were collected using a modification of the method described by Stamey and Condy. ${ }^{1}$ A Cusco bivalve speculum was passed and the vagina washed out with four 10-ml aliquots of distilled water, giving a total of $40 \mathrm{ml}$ of washings. A 5-ml plasma sample was then collected. Samples were only collected after the end of the last menstrual period, and no sample was taken if there was cervical or vaginal bleeding from any cause.

\section{Results}

PLASMA

A typical standard curve for erythromycin concentrations in plasma by the microbiological assay is shown in fig 1. At high concentrations small differences in the size of the zone of inhibition $(50-70 \mathrm{~mm})$ correspond to large differences in concentration $(0 \cdot 25-3 \mu \mathrm{g} / \mathrm{ml})$.

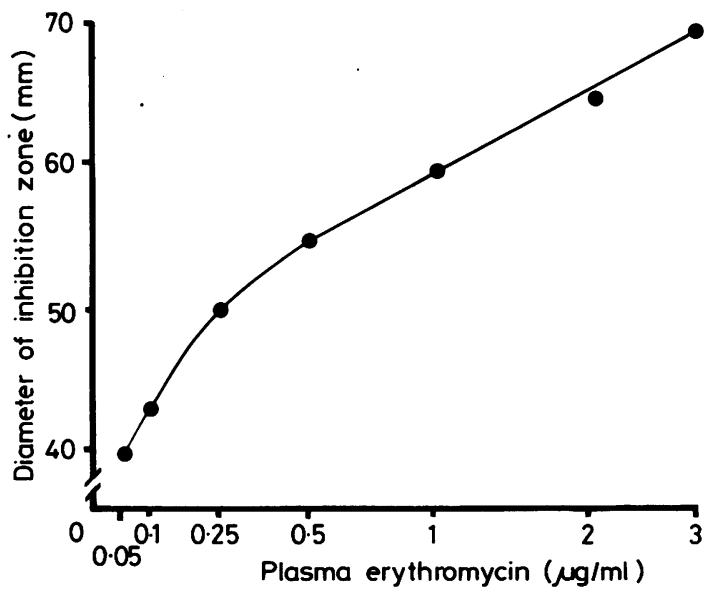

FIG 1 Typical standard curve for erythromycin in spiked human plasma by microbiological assay.

The mean standard curve for erythromycin in plasma from six separate assays by the fluorimetric method is shown in fig 2 . There is a linear relationship between plasma concentration and fluorescence intensity. At high concentrations this assay gave a clear separation in fluorescence intensity.

VAGINAL WASHINGS

The mean standard curve for erythromycin in vaginal washings from four separate assays by the fluorimetric method is shown in fig 3 . There is a similar

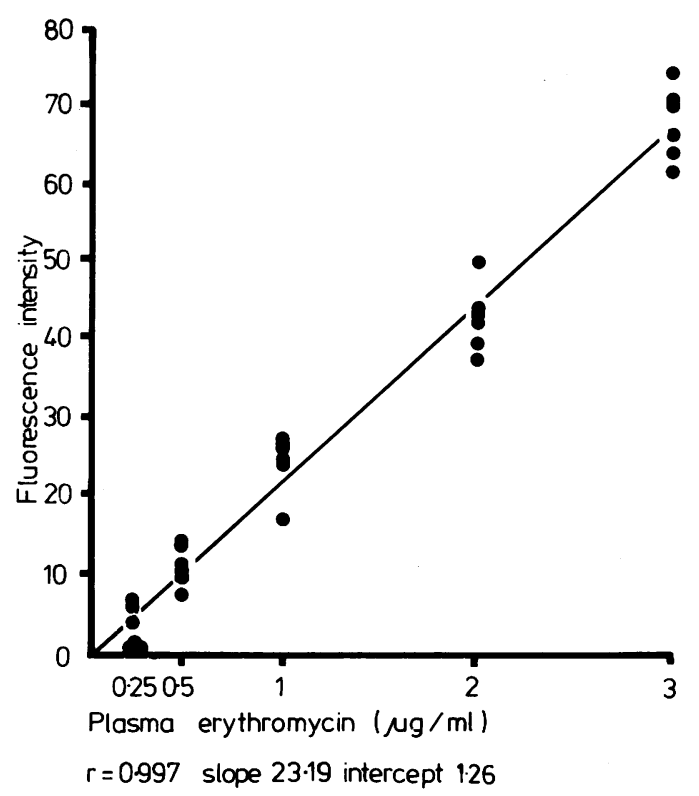

FIG 2 Mean standard curve for erythromycin in spiked human plasma from six separate fluorimetric assays.

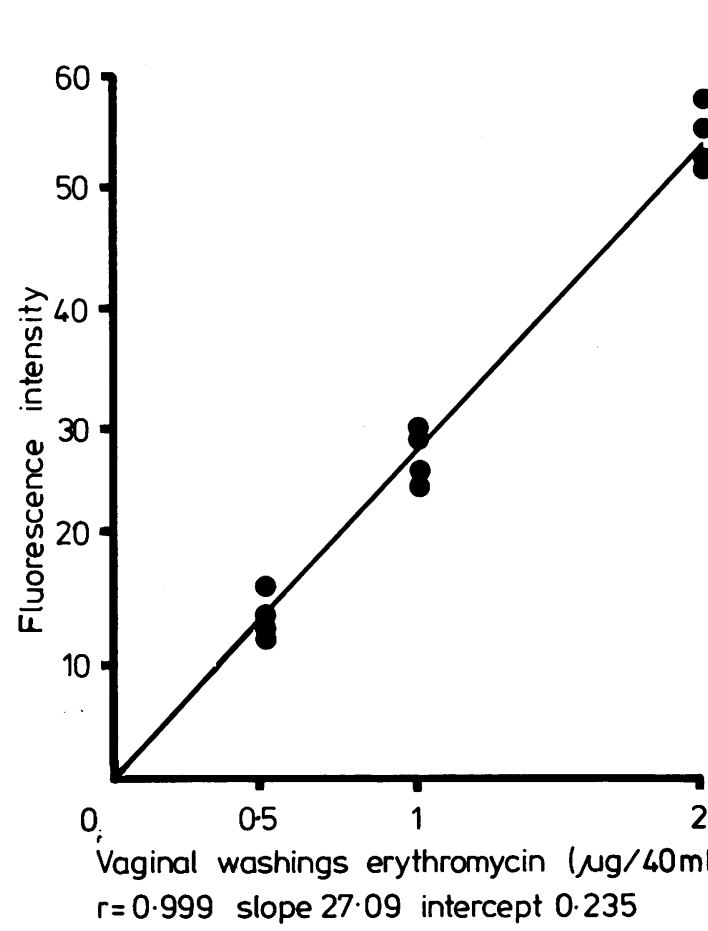

FIG 3 Mean standard curve for erythromycin in spiked vaginal washings from four separate fluorimetric assays. 
pattern to that of plasma with a clear separation of fluorescence intensity between concentrations.

\section{COMPARISON OF ASSAYS}

The coefficient of variation (CV) in spiked plasma samples for the microbiological and fluorimetric assays from six separate assays for each concentration is given in table I. The CV with the fluorimetric method is poor at extremely low concentrations but is satisfactory at higher concentrations. The microbiological assay gives satisfactory precision at all concentrations.

TABLE I Coefficient of variation (CV) of the two analytical methods from six separate assays for each concentration of erythromycin

\begin{tabular}{lll}
\hline & \multicolumn{2}{c}{ Coefficient of variation $(\%)$ by: } \\
\cline { 2 - 3 } $\begin{array}{ll}\text { Plasma erythromycin } \\
\text { concentration }(\mu \mathrm{g} / \mathrm{ml})\end{array}$ & $\begin{array}{l}\text { Microbiological } \\
\text { assay }\end{array}$ & $\begin{array}{l}\text { Fluorimetric } \\
\text { assay }\end{array}$ \\
\hline 0.05 & $12 \cdot 2$ & \\
$0 \cdot 1$ & $7 \cdot 1$ & \\
$0 \cdot 25$ & $5 \cdot 6$ & $114 \cdot 5$ \\
0.5 & $5 \cdot 1$ & $18 \cdot 3$ \\
1 & $4 \cdot 9$ & $14 \cdot 5$ \\
2 & $4 \cdot 8$ & $9 \cdot 6$ \\
3 & $5 \cdot 7$ & $6 \cdot 6$ \\
\hline
\end{tabular}

The correlation between fluorimetric and microbiological assays in plasma samples is shown in fig 4 .

The mean plasma concentrations $( \pm$ SE) of both groups of patients by both assays showed high concentrations in the men, whereas those in the women, although lower, were higher than the minimum inhibitory concentration (MIC) for sensitive organisms, which varies from $<0 \cdot 1$ to about $2 \mu \mathrm{g} / \mathrm{ml}$ (fig 5)..$^{45}$ The concentrations in plasma and vaginal washings taken simultaneously from the 11 women two hours after the final $250-\mathrm{mg}$ dose of 10 days' treatment, as estimated by the fluorimetric assay, were $0 \cdot 68 \pm 0 \cdot 15 \mu \mathrm{g} / \mathrm{ml}$ and $0 \cdot 50 \pm 0 \cdot 16 \mu \mathrm{g} / 40 \mathrm{ml}$ respectively.

The concentrations in vaginal washings are expressed as $\mu \mathrm{g} / 40 \mathrm{ml}$ of washings because these values were obtained by the fluorimetric assay by extracting the drug from the total sample volume of $40 \mathrm{ml}$. Eight $1-\mathrm{ml}$ samples of vaginal washings were subjected in duplicate to the microbiological assay; in all eight, drug concentrations were below the limit of detection $(0.05 \mu \mathrm{g} / \mathrm{ml})$ and bacterial contamination was present.

The individual results for plasma and vaginal washings by the fluorimetric assay are shown in fig 6 . Of the 11 patients, four had detectable concentrations of erythromycin in plasma but not in vaginal washings. In one patient no concentration was detectable in plasma but was in vaginal washings,
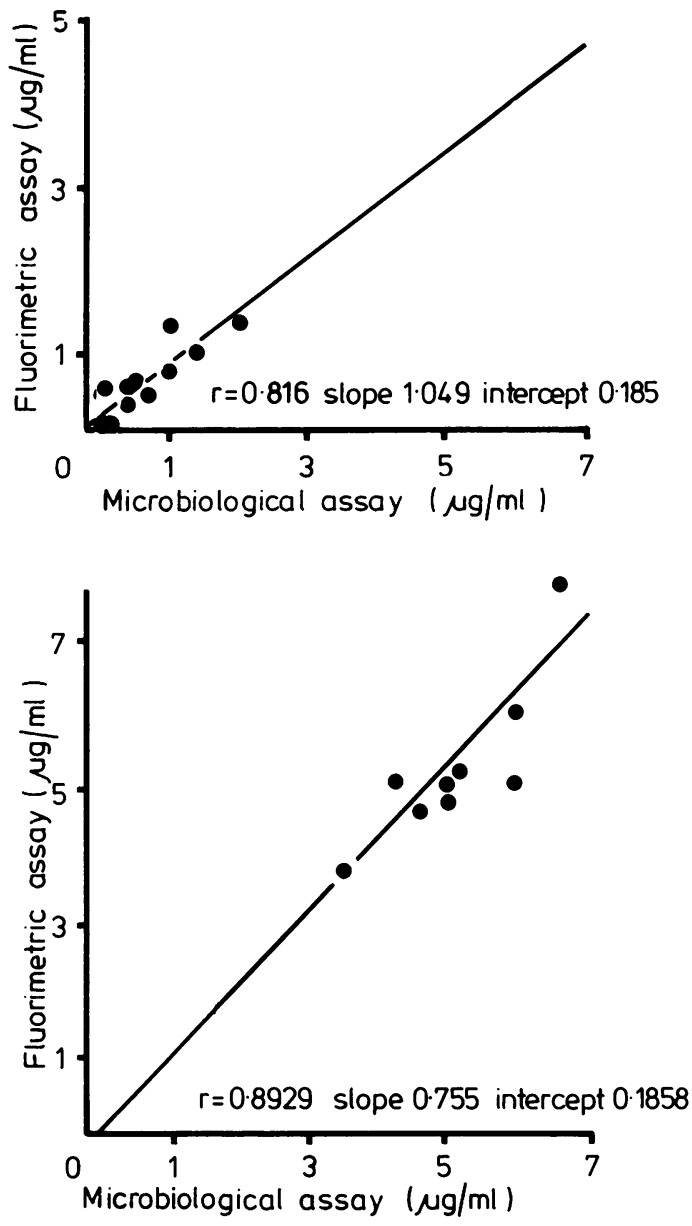

FIG 4 Correlation between fluorimetric and microbiological assays in plasma samples. Lower graph shows values from the nine men one hour after a single dose and the upper graph values from the 11 women on regular dosage.

whereas in one patient no erythromycin was detectable in either sample. All these results have been included in the mean values for plasma and vaginal washings given above. All eleven patients claimed to have taken their tablets regularly, the last dose being two hours before sampling.

\section{Discussion}

Factors that influence the efficacy of treatment of bacterial and chlamydial infections include the susceptibility of the organism to antibiotics and the penetration of drugs to the site of infection. 


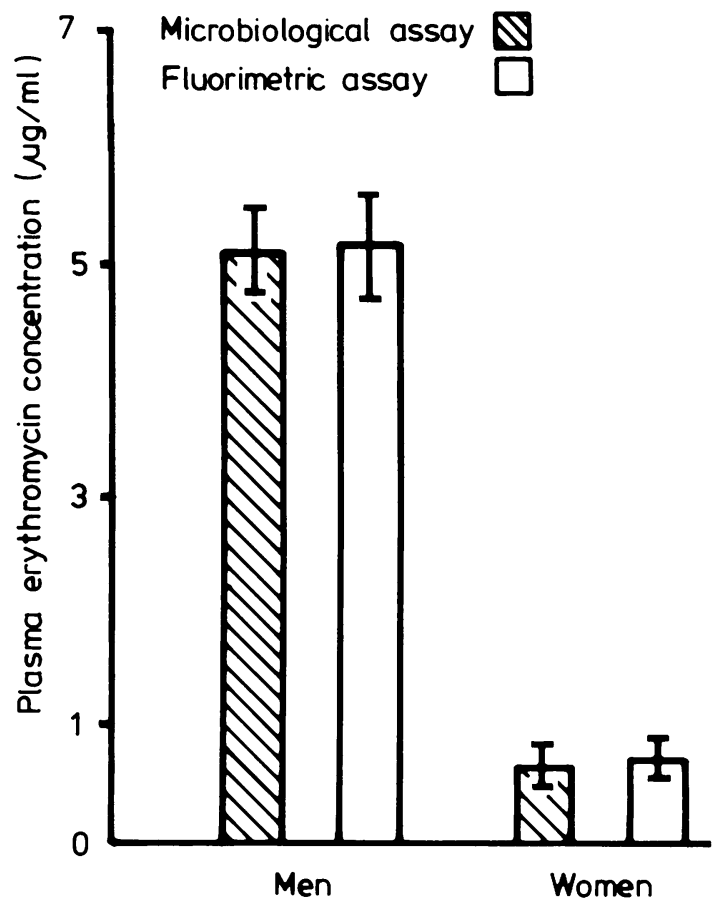

FIG 5 Mean plasma erythromycin concentrations $( \pm S E)$ by the microbiological and fluorimetric assays in nine men $(5 \cdot 13 \pm 0 \cdot 32$ and $5 \cdot 20 \pm 0.43 \mu \mathrm{g} / \mathrm{ml}$ respectively) and in 11 women $10.65 \pm 0.18$ and $0.68 \pm 0.15 \mu \mathrm{g} / \mathrm{ml}$ respectively).

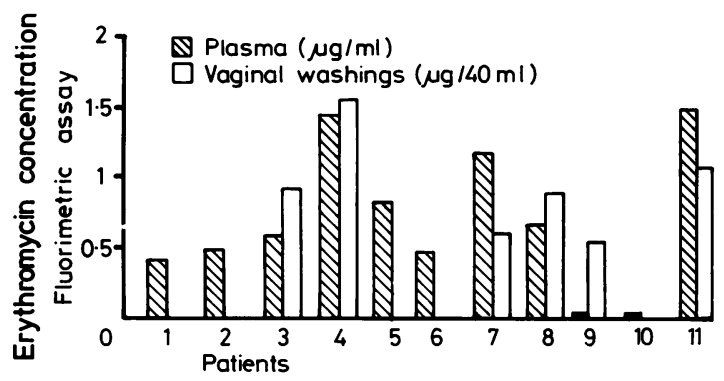

FIG 6 Erythromycin concentrations in plasma and vaginal washings of 11 women.

These microbiological and fluorimetric assays were developed to study the pharmacokinetics of erythromycin in relation to its penetration into body fluids and secretions. Evaluation of the two methods showed that the Sarcina lutea microbiological method was more sensitive in determining concentrations in plasma but not sensitive enough for determining those in vaginal washings. This was because the concentrations of erythromycin present in the $1-\mathrm{ml}$ samples of vaginal washings, which is the specimen volume required for the assay, were $\frac{D}{\infty}$ extremely low and also because the specimens being assayed were not sterile. This assay should be restricted to sterile specimens.

In contrast, the fluorimetric assay has the property of extracting any measurable amount of drug from any sample volume, whether sterile or not. The $\mathbb{\Phi}$ fluorimetric assay can produce results within two hours, whereas the microbiological method takes at least 24 hours. The fluorimetric assay may be of $\vec{O}$ more value for clinical purposes but it is more costly and requires experience.

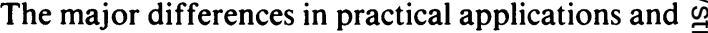
technical limitations between these two assays are or summarised in table II.

TABLE II A comparison of the principal features of the two assay methods

\begin{tabular}{|c|c|c|}
\hline \multirow[b]{2}{*}{ Features } & \multicolumn{2}{|l|}{ Assay } \\
\hline & Fluorimetric & Microbiological \\
\hline Specificity & High & Poor \\
\hline $\begin{array}{l}\text { Susceptibility to } \\
\text { interference by: } \\
\text { Bacteria } \\
\text { Other antibiotics } \\
\text { Related compounds }\end{array}$ & $\begin{array}{l}\text { No } \\
\text { No } \\
\text { No }\end{array}$ & $\begin{array}{l}\text { Yes } \\
\text { Yes } \\
\text { No }\end{array}$ \\
\hline Sensitivity & Fair & Good \\
\hline Range of measurable values & $0.5-3 \mu \mathrm{g} / \mathrm{ml}$ & $0.05-3 \mu \mathrm{g} / \mathrm{ml}$ \\
\hline $\begin{array}{l}\text { Reproducibility at low } \\
\text { concentrations }\end{array}$ & Poor & Good \\
\hline $\begin{array}{l}\text { Reproducibility at high } \\
\text { concentrations }\end{array}$ & Good & Good \\
\hline $\begin{array}{l}\text { Sample volume required } \\
\text { for assay }\end{array}$ & $1 \mathrm{ml}^{*}$ (at least) & $0.5-1 \mathrm{ml}$ (at most) \\
\hline Assay duration & $2 \mathrm{~h}$ & $24-28 \mathrm{~h}$ \\
\hline $\begin{array}{l}\text { Convenience of performance: } \\
\text { Special equipment } \\
\text { Special training }\end{array}$ & $\begin{array}{l}\text { Yes } \\
\text { Yes }\end{array}$ & $\begin{array}{l}\text { No } \\
\text { No }\end{array}$ \\
\hline Standardisation of assay & Objective & Individual \\
\hline $\begin{array}{l}\text { Material cost of assay } \\
\text { per } 7 \text { duplicate samples } \\
\text { (at June 1980) }\end{array}$ & $f 1 \cdot 85$ & $£ 0 \cdot 20$ \\
\hline $\begin{array}{r}\text { Operator time per } 7 \\
\text { duplicate samples }\end{array}$ & $2-3 \mathrm{~h}$ & $2-3 \mathrm{~h}$ \\
\hline
\end{tabular}

The correlation between the two assays in deter- $\tilde{O}$ mining plasma concentrations of erythromycin was $\underset{\mathrm{N}}{ }$ satisfactory. Relatively high concentrations were present in the nine men one hour after a 2-g single 0 dose; lower concentrations, but within the therapeutic $\stackrel{\overparen{D}}{\overparen{D}}$ range, occurred in the 11 women given erythromycin $250 \mathrm{mg}$ four times daily for 10 days. Plasma con- $T$ centrations do not predict the therapeutic efficacy of $\bar{O}$ a drug but indicate its clinical effect. In this study all $\stackrel{\mathbb{D}}{\Omega}$ measurable plasma erythromycin concentrations were above the MIC for Neisseria gonorrhoeae, 
which is given as $0.04-0.4 \mu \mathrm{g} / \mathrm{ml}$ by Garrod and O'Grady. ${ }^{6} \mathrm{~A}$ recent survey of strains isolated in this hospital, however, gave the range as $0 \cdot 03-0 \cdot 25 \mu \mathrm{g} / \mathrm{ml}$ (personal communication, 1980). The MIC for Chlamydia trachomatis (the most notable organism found in the genital tract in non-specific genital infection) is $0 \cdot 03-0 \cdot 12 \mu \mathrm{g} / \mathrm{ml}^{5}$

The concentration of erythromycin in the vaginal fluid was not measured directly, but the figure in $\mu \mathrm{g} / 40 \mathrm{ml}$ of washings provides an exact measure of the total quantity of erythromycin recovered from the vagina and may therefore also provide a guide to the concentration of drug in the target tract. Our figure, although not providing a value for the concentration of the drug in vaginal washings as does the method of Stamey and Condy, ' may on further evaluation prove to be a reliable and simple index for tissue diffusion of drugs.

Estimation of vaginal concentrations of drugs used to treat infections of the lower genital tract should provide a more reliable indication of clinical efficacy than plasma concentrations. The two taken together may be useful in monitoring compliance by patients in adhering to drug regimens.

Our results suggest that the patient (No 9) in whom drug concentrations were detected in the vagina but not in the plasma had taken medication until the day of attendance. On the other hand, those with concentrations in the plasma but not in the vagina may have taken their tablets irregularly but remembered to do so just before attending the clinic. The patient (No 10) who had no drug detectable in plasma or vaginal washings may not have taken any tablets for some time.

More work is required to establish the time course for the appearance of the drug in vaginal secretions and for the attainment of equilibrium as well as for the persistence of the drug in the vagina when plasma concentrations have become undetectable, since the two may not be related. Knowledge of the local pharmacokinetics could lead to more rational therapeutic regimens and to a more critical assessment of patient compliance. Although measurements such as these are too sophisticated for routine use, they may be valuable in assessing new preparations of formulations, monitoring compliance during drug trials, or investigating patients with an unsatisfactory clinical response. Thus measurement of drugs in vaginal washings could be of practical clinical application as well as providing a model of drug penetration in a target organ.

The authors thank Dr S Tabaqchali (Bacteriology Department, St Bartholomew's Hospital) and Dr J Henry (Department of Clinical Pharmacology) for their helpful discussions and suggestions; Sister K Touzel, Mr R Gwyne and the staff of the Department of Genital Medicine for their enthusiastic cooperation; and also Mr H B Thomas, Abbot Laboratories, for supplying erythromycin (analytical grade).

\section{References}

1. Stamey TA, Condy M. The diffusion and concentration of trimethoprim in human vaginal fluid. $J$ Infect Dis 1975; 131:261-6.

2. Bell SC, Hamman JW, Grundy WE. Micromethod for assaying serum levels of erythromycin. Appl Microbiol 1969; 17:88-92.

3. Tserng K, Wagner JG. Fluorimetric determination of erythromycin and erythromycin propionate in whole blood or plasma and correlation of results with microbiological assay. Analytical Chemistry 1976; 48: 348-53.

4. Martindale. The Extra Pharmacopoeia, 27th ed. London: Pharmaceutical Press, 1977: 1130.

5. Ridgway GL, Owen JM, Oriel JD. The antimicrobial susceptibility of Chlamydia trachomatis in cell culture. Br J Vener Dis 1978;54: 103-6.

6. Garrod LP, O'Grady F. Antibiotic and Chemotherapy, 3rd ed. Edinburgh and London: E \& S Livingstone, 1971:167. 